phẫu bệnh- Sinh học phân tử, Bệnh viện K, cơ sở Tân Triều, chúng tôi rút ra kết luận sau:

- UTBMNTG thường gặp ở nữ, tỷ lệ nữ/nam là 7,3/1. Tuổi trung bình mắc bệnh là $37,5 \pm 14, U$ thường gặp ở thùy phải chiếm 43,4\%.

- Xác định 10/15 biến thể bao gồm: thông thường $(21,2 \%)$, vi ung thư biểu mô nhú $(17,2 \%)$, xơ hóa lan tỏa và tế bào cao $(16,2 \%)$, có vỏ $(11,1 \%)$, nang $(9,1 \%)$, ái toan $(6,0 \%)$ và $1 \%$ các biến thể dạng sàng phôi dâu, giống Warthin và đăc.

Mỗi biến thể có đặc điểm cấu trúc và hình thái tế bào khác nhau nhưng có chung đặc điểm nhân của UTBMNTG. Các biến thể UTBMNTG được sắp xếp vào các nhóm nguy cơ khác nhau. Do đó,chẩn đoán các biến thể mô bệnh học của UTBMNTG trên lâm sàng là thực sự cân thiết và hữu ích cho các nhà lâm sàng trong việc điều trị và tiên lượng cho bệnh nhân.

\section{TÀI LIỆ THAM KHẢO}

1. Ferlay J, Colombet $M$, Soerjomataram $I$, et al (2021). "Cancer statistics for the year 2020: An overview". Int J Cancer,

2. Lloyd RV, Osamura RY, Klöppel G, et al (2017). WHO Classification of Tumours of Endocrine Organs, Lyon, 10,
3. Song $E$, Jeon $M$ J, Oh H S, et al (2018). "Do aggressive variants of papillary thyroid carcinoma have worse clinical outcome than classic papillary thyroid carcinoma?". Eur J Endocrinol, 179 (3), 135-142.

4. Trân Ngọc Dũng (2012). Nghiên cựu phân loại mô bệnh học và giá trị của hóa mô miến dịch trong chẩn đoán ung thư biểu mô tuyến giáp. Luận văn Tiến sỹ y học: Trường Đại học Y Hà Nội.

5. Đinh Xuân Cường (2010). Nghiên cứu đăc điểm lâm sàng, mô bệnh học và kết quả điều trị giải phẫu bệnh ung thư tuyến giáp tại bệnh viển $\mathrm{K}$. Luân văn Thac sỹ y hoc. Hà Nội: Trường Đại học Y Hà Nội.

6. Pham Duy Đat (2019). Nghiên cứu đăc điểm giải phẫu bệnh và bộc lộ BRAF V600E bằng hóa mô miển dich trong ung thư biểu mô nhú tuyến giáp. Luận vằn Bác sĩ chuyên khoa II. Hà Nội: Đại học Y Hà Nội.

7. Chereau $N$, Giudicelli $X$, Pattou $F$, et al (2016). "Diffuse Sclerosing Variant of Papillary Thyroid Carcinoma Is Associated With Aggressive Histopathological Features and a Poor Outcome: Results of a Large Multicentric Study". J Clin Endocrinol Metab, 101 (12), 4603-4610.

8. Carr A A, Yen T W F, Ortiz D I, et al (2018). "Patients with Oncocytic Variant Papillary Thyroid Carcinoma Have a Similar Prognosis to Matched Classical Papillary Thyroid Carcinoma Controls". Thyroid, 28 (11), 1462-1467.

\title{
NGHIÊN CỨU ĐĂC ĐIỂM TẾ BÀO TỦY XƯƠNG VÀ KHỐI TẾ BÀO GỐC TÁCH TỪ DİCH TUỶ XƯƠNG CỦA BỂNH NHÂN THOÁI HÓA KHỚP GỐI
}

\section{TÓM TẮT}

Từ tháng 11/2011-10/2013 chúng tôi đã tiến hành nghiên cứu ứng điều trị thoái hóa khớp gối (THKG) bằng nội soi tạo tổn thương dưới sụn (microfracture) kết hợp ghép khối tế bào gốc tủy xương tự thân (TBGTXTT) cho 46 bệnh nhân. Mục tiêu: 1) Nghiên cứu một số chỉ số của khối TBG tủy xương tự thân của bệnh nhân THKG. Đối tượng và phướng pháp nghiên cứu: Dịch tuỷ xương được lấy từ xương chậu của 46 bệnh nhân THKG tiên phát giai đoạn 2 và 3 , trước khi được phẫu thuật nội soi tạo tổn thương dưới sụn và ghép khối TBGTXTT. Xác định số lượng tế bào có nhân của tuỷ xương bằng máy huyết học tự động CELL-DYN 1800. Khối TBG được tách bằng phương pháp ly tâm tỷ trọng. Xác định thành phân TBG tạo máu $\mathrm{CD} 43(+)$ bằng phương pháp tế bào dòng chảy,

\section{${ }^{1}$ Đại Họ Y Hà Nội}

Bệnh viện Trung Ương Quân đội 108

Chịu trách nhiệm chính: Dương Đình Toàn

Email: duongdinhtoan@hmu.edu.vn

Ngày nhận bài: 10.5.2021

Ngày phản biên khoa hoc: 2.7.2021

Ngày duyệt bài: 14.7.2021

\section{Dương Đình Toàn ${ }^{1}$, Nguyễn Thị Thu Hà ${ }^{2}$}

xác định TBG trung mô bằng kỹ thuật nuôi cấy cụm nguyên bào sợi CFU-F. Kết quả: Số lượng tế bào có nhân tủy xương trung bình là $69,03 \pm 49,86 \mathrm{G} / \mathrm{L}$, trong đó tỷ lệ tế bào gốc CD34(+) tủy xương trung bình chiếm $0,71 \pm 0,78 \%$. Trong khối TBG được tiêm vào khớp gối, số lượng TBG CD34(+) trung bình là $8,15 x$ $10^{6}$, số lượng tế bào tạo cụm CFU-F trung bình là $33,34 \times 10^{3}$. Kết luận: TBG được lấy từ dịch tuỷ xương của nhóm bệnh nhân thoái hoá khớp gối tiên phát giai đoạn 2, 3 không qua nuôi cấy có thể sử dụng hiệu quả trong điều trị bệnh thoái hoá khớp gối .

Tư khóa: thoái hóa khớp gối, nội soi khớp gối, ghép tế bào gốc.

\section{SUMMARY}

RESEARCH ON THE CHARACTERISTICS OF BONE MARROW CELLS AND AUTOLOGOUS

BONE MARROW STEM CELLS ISOLATED

FROM BONE MARROW FLUID OF PATIENTS WITH KNEE OSTEOARTHRITIS

Background: From 11/2011 to 10/2013, forty-six patients with forty-six knee osteoarthritis (KOA) underwent Arthroscopic Subchondral Drilling (microfracture) in combination with Autologous Bone 
Marrow Stem cells (ABMSCs) injection. Objectives: 1) Investigate some indexes of ABMSCs block of patients with KOA. Subjects and Methods: Forty-six primary KOA underwent ASD in combination with ABMSCs injection from pelvis. Most of knees had grade 3 cartilage lesions. Results: The average number of nucleated cells was $69.03 \pm 49.86 \mathrm{G} / \mathrm{L}$, in which the average percentage of $\mathrm{CD} 34(+)$ stem cells used 0.71 $\pm 0.78 \%$. The number of CD34(+) cells obtained in Autologous Bone Marrow blocks average 8,15 $\pm 0,67$ $\mathrm{x} 10^{6}$. The number of cells that create clusters of CFU-F average $33,34 \pm 39,98 \times 10^{3}$. Conclusion: tem cells obtained from bone marrow fluid of patients with primary knee osteoarthritis stage 2 and 3 without culture can be used effectively in the treatment of knee osteoarthritis.

Keyword: Osteoarthritis, bone marrow stem cell, arthroscopy, microfracture

\section{I. ĐẶT VẤN ĐỀ}

Thoái hóa khớp gối (THKG) là bệnh thường gặp trong nhóm bệnh lý mãn tính của người có tuổi, gây ảnh hưởing lớn đến chất lượng cuộc sống của người bệnh. Tổn thương đặc trưng của THKG là sự bong gãy, mất dần sụn khớp do hậu quả của sự mất cân bằng giữa quá trình sinh tổng hợp và hủy hoại sụn khớp [1]. Khi sụn khớp bị tổn thương hay già hóa, sụn không có khả nằng tự phục hồi do không có mạch nuôii, vì vậy, điều trị THKG ở giai đoạn đầu chì là điều trị triệu chứng. Với khả năng tự tái tạo và biệt hóa thành những tế bào chuyên biệt, đa dòng trong những điều kiện nhất định, tế bào gốc (TBG) được xem như là một nguồn "nguyên liệu" dự trữ của cơ thể để sửa chữa, tái tạo, thay thế những mô, tổ chức bị tổn thương hay già hóa, trong đó có mô sụn [2]. Trên thế giới, đã có nhiều công trình nghiên cứu ở các giai đoạn tiên lâm sàng và thử nghiệm lâm sàng, đã chứng minh khả năng tăng sinh, biệt hóa thành tế bào sụn từ TBG, giúp phục hồi mô sụn, như nghiên cứu của Wakitani (1994) [3], Centeno và cộng sự [4]. Hiện nay ứng dụng TBG trong điều trị bệnh thoái hoá khớp gối, nguồn TBG được lấy chủ yếu từ mô mõ và dịch tuỷ xương (DTX), trong đó DTX vẫn là nguồn TBG được sử dụng phổ biến bởi độ tuổi và khả năng biệt hoá của các loại tế bào. Để làm rõ thêm một số đặc điểm bào tuỷ xương của bệnh nhân THKG, chúng tôi thực hiện đề tài nhằm mục tiêu: Nghiên cứu đăc điểm một số chi số tế bào tủy xương và khối tế bào gốc tách từ dịch tuỷ xương của bệnh nhân thoái hóa khớp gối.

II. ĐỐI TƯợNG VÀ PHƯƠNG PHÁP NGHIÊN CỨU

Là những bệnh nhân THKG tiên phát giai đoạn 2 và 3 , được điều trị bằng phẫu thuật nội soi tạo tổn thương dưới sụn và ghép khối tế bào gốc tuỷ xương tự thân tại bệnh viện Việt Đức

\subsection{Tiêu chuẩn lựa chọn bệnh nhân}

+Là những bệnh nhân có THKG tiên phát, được chẩn đoán theo tiêu chuẩn của hội Khớp học Hoa Kỳ (ACR) 1991 [5]

+Thoái hoá khớp gối giai đoạn II và III (theo tiêu chuẩn của Kellgren-Lawrence [6]).

+ Tuổi từ 40-70.

+ Không phân biệt nghề nghiệp, giới.

\subsection{Tiêu chuẩn loại trừ}

+ Có bệnh lý về cơ quan tạo máu, ung thư, có thai, suy giảm miễn dịch

+ Có viêm nhiễm vùng xương chậu (vị trí lấy dịch tủy xương)

2.3.Thiết kế nghiên cứu: mô tả cắt ngang tiến cứu

2.4. Cỡ mẫu: cỡ mẫu thuận tiện, gồm 46 bệnh nhân, được lựa chọn theo tiêu chuẩn lựa chọn.

2.5. Thợi gian và đia điểm nghiên cứu

- Thời gian nghiên cứu: Nghiên cứu này được tiến hành từ tháng 11 năm 2011 đến tháng 1 năm 2015.

- Địa điểm nghiên cứu: Viện Chấn thương Chỉnh hình, Bệnh viện Việt Đức; khoa Huyết Học, khoa Chẩn Đoán Hình Ảnh, Bệnh viện Trung Ương Quân Đội 108.

\subsection{Quy trình nghiên cứu:}

Chọc hút DTX từ xương chậu bệnh nhân, được tiến hành tại phòng mổ Bệnh viện Việt Đức; xử lý DTX, tách khối TBG được thực hiện tại khoa Huyết học Bệnh viện TWQĐ 108. Quá trình thu gom được tiến hành trong điều kiện vô trùng tuyệt đối.

Xác định số lượng tế bào có nhân của tuỷ xương bằng máy huyết học tự động CELL-DYN 1800 (Abbot- Hoa Kỳ).

- Phân loai tỷ lệ \% các loại tế bào tuỷ và xem xét hình thái tế bào trên tiêu bản tủy dàn nhuộm Giemsa.

- Tách khối TBG từ DTX theo phương pháp ly tâm gradient tỷ trọng, cô đặc trong $10 \mathrm{ml}$

- Các xét nghiềm tế bào máu và tủy xương:

+ Huyết đồ và tủy đồ: theo phương pháp tế bào hoc kinh điển kết hợp với phân tích tế bào bằng hệ thống phân tích huyết học tự động.

+ Xác định số lượng tế bào gốc tuỷ xương (TBGTX):

TBG tao máu:bằng phương pháp tế bào dòng chảy dựa vào các marker bề mặt đặc hiệu CD34(+) theo protocol của ISHAGE.

TBG trung mô: bằng kỹ thuật nuôi cấy tạo cụm CFU-F [7]. 
Quy trình được tóm tắt bằng sơ đồ sau:

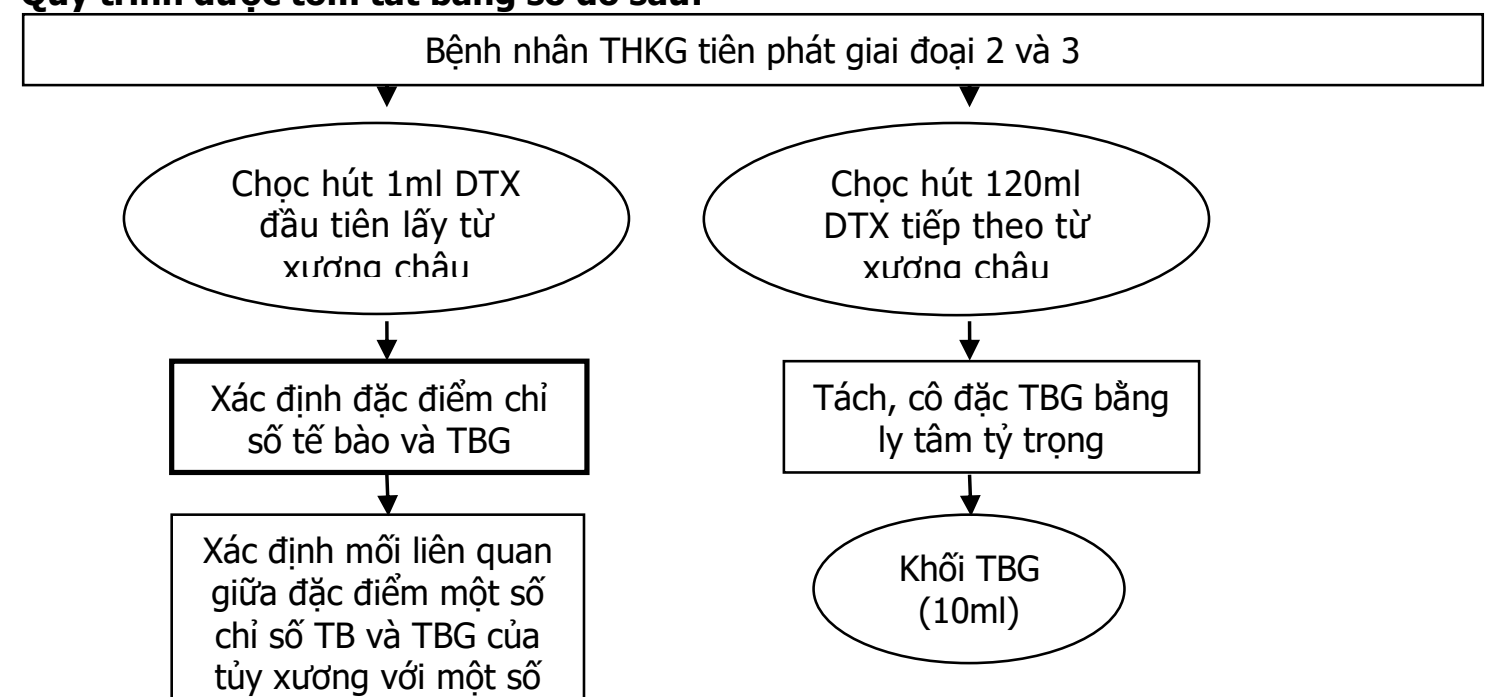

2.8. Đạo đức nghiên cứu. Chúng tôi thực

2.7. Các chỉ tiêu nghiên cứu

- Đặc điểm chung của đối tượng nghiên cứu: tuổi, giới, nghề nghiêp

- Đặc điểm một số chỉ số của tế bào gốc của tủy xương

- Số lượng tế bào có nhân, số lượng và tỷ lệ

TBG tạo máu

- Mối liên quan giữa các thành phần tế bào có nhân, TBG tạo máu với tuổi

- Đặc điểm khối tế bào gốc được tách từ dịch tủy xương

- Đặc điểm thành phần các tế bào và TBG tạo máu, đặc điểm thành phần TBG trung mô với tuổi

- Tương quan giữa số lượng TBG trung mô

Bảng 1. Phân bố TB tuỷ xương của nhóm nghiên cứu (n=46)

\begin{tabular}{|c|c|c|c|c|}
\hline Chỉ số TB & Đơn vị & Giá trị trung bình & Giá trị nhỏ nhất & Giá trị lớn nhất \\
\hline Số lượng TB có nhân & $\mathrm{G} / \mathrm{L}$ & $69,03 \pm 49,86$ & 20 & 255 \\
\hline Tỷ lệ TB CD34(+) & $\%$ & $0,71 \pm 0,78$ & 0,24 & 5,07 \\
\hline
\end{tabular}

Nhận xét: số lượng tế bào có nhân tủy xương trung bình là $69,03 \pm 49,86$, tỷ lệ tế bào CD34(+) trung bình $0,71 \pm 0,78(\%)$.

Bảng 2. Phân bố TB tuỷ xương theo tuổi

\begin{tabular}{|c|c|c|c|c|}
\hline \multirow{2}{*}{ Chỉ số TB } & \multirow{2}{*}{ Đơn vị } & \multicolumn{2}{|c|}{ Nhóm tuối } & \multirow{2}{*}{ p } \\
\cline { 3 - 5 } & & $\leq 55(\mathrm{n}=26)$ & $>55(\mathrm{n}=20)$ & $>0,05$ \\
\hline TB có nhân & $\mathrm{G} / \mathrm{L}$ & $77,28 \pm 50,33$ & $58,31 \pm 48,37$ & $>0,05$ \\
\hline CD34(+) & $\%$ & $0,61 \pm 0,37$ & $0,84 \pm 1,1$ & \\
\hline
\end{tabular}

Nhận xét: - Số lượng tế bào có nhân ở nhóm bệnh nhân trên 55 tuổi có xu hướng thấp hơn so với nhóm bệnh nhân dưới 55 tuổi, tuy nhiên sự khác biệt này không có ý nghĩa thống kê với p>0,05.

- Tỷ lệ và số lượng tế bào CD34(+) giữa hai nhóm không có sự khác biệt.

3.3. Đặc điểm khối TBG tách từ DTX 
Bảng 3. Đặc điểm thành phần các TB và TBG tạo máu ( $n=46)$

\begin{tabular}{|c|c|c|c|c|}
\hline TB tủy xướng & Đơn vị & Giá trị trung bình & Giá trị nhỏ nhất & Giá trị lớn nhất \\
\hline Số lượng TB có nhân & $\mathrm{G} / \mathrm{L}$ & $66,33 \pm 46,12$ & 6,4 & 225 \\
\hline Số lượng TB đớn nhân & $\%$ & $60,05 \pm 14,98$ & 30,2 & 89,6 \\
\hline Tỷ lệ TB CD34(+) & $\%$ & $1,44 \pm 0,67$ & 0,44 & 3,18 \\
\hline Số lượng TB CD34(+) & $\times 10^{6}$ & $8,15 \pm 5,5$ & 1,1 & 22,78 \\
\hline Số lượng tiếu cầu & $\mathrm{G} / \mathrm{L}$ & $468,26 \pm 306,24$ & 30 & 1300 \\
\hline Tỷ lệ TB sống & $\%$ & $95,67 \pm 1,33$ & 93 & 99 \\
\hline
\end{tabular}

Nhận xét: - Nồng độ tế bào có nhân trong khối TBG trung bình là 66,33 $\pm 46,12 \mathrm{G} / \mathrm{L}$.

- Tỷ lệ tế bào đớn nhân trong khối TBG trung bình là $60,05 \pm 14,98 \%$

- Tỷ lệ tế bào CD34(+) trong khối TBG tăng cao hơn so với trước tách (trước tách $0,71 \pm$ $0,78 \%$, sau tách $1,44 \pm 0,67 \%)$.

- Tổng số lượng tế bào gốc CD34(+) sau tách trung bình là $8,15 \pm 5,5 \times 10^{6}$.

- Tỷ lệ tế bào sống đều trên $90 \%$, trung bình là $95,67 \pm 1,33 \%$.

- Tương quan giữa số lượng tế bào CD34(+) với số lượng TB có nhẩn

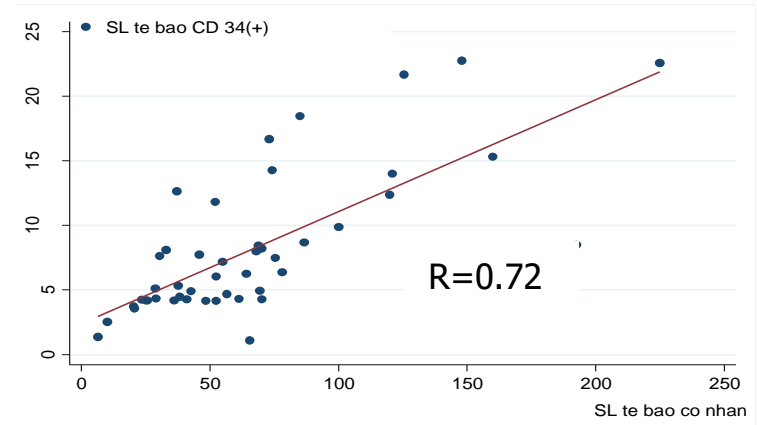

Biểu đồ 1: Tương quan giữa số lượng tê" bào $C D 34(+)$ với số lượng tê bào có nhân

Nhận xét: từ Biểu đồ 3.6 ta thây, số lượng tế bào CD34(+) trong khối TBGTX sau tách có tương quan tỷ lệ thuận với số lượng tế bào có nhân, với $r=0,72$.

Bảng 4. Số lượng TBG trung mô (TB tạo cụm CFU-F) ( $n=41$ )

\begin{tabular}{|c|c|c|c|}
\hline & Giá trị trung bình & $\begin{array}{c}\text { Giá trị } \\
\text { nhỏ nhất }\end{array}$ & $\begin{array}{c}\text { Giá trị } \\
\text { lớn nhất }\end{array}$ \\
\hline Cụm CFU-F/10 TB & $43,17 \pm 25,23$ & 7 & 140 \\
\hline Cụm CFU-F/ml khối TBGTX & $3336,83 \pm 3996,59$ & 283,9 & 22698 \\
\hline TB tạo cụm CFU-F được bơm vào khớp gối & $33343,88 \pm 39984,11$ & 2838 & 226980 \\
\hline
\end{tabular}

Nhận xét: - Số lượng cụm CFU-F thu được khi nuồi cầy từ $1 \times 10^{6}$ tế bào trong khối TBGTX trung bình là 43,17 $\pm 25,23$ (7-140).

- Số lượng cụm tế bào CFU-F thu được khi nuôi cấy từ $1 \mathrm{ml}$ khối TBGTX trung bình là 3336,83 (284-22698)

- Tương quan giữa số cụm CFU-F với tuổi

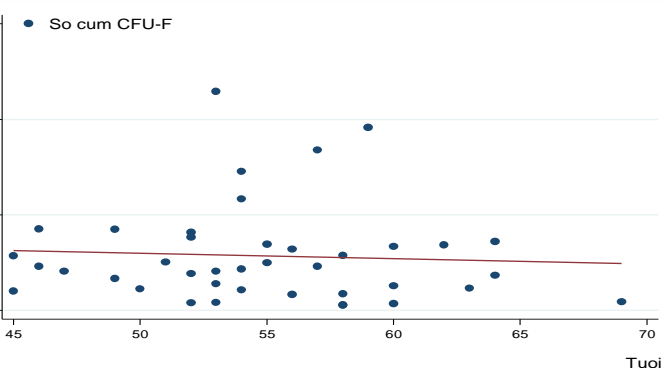

Biểu đồ 2: Môii tương quan giữa tuổi bệnh nhân và số lượng cum CFU-F.

Nhận xét: số lượng TBG trung mô (số lượng cụm CFU-F) có xu hướng tương quan tỷ lệ nghịch với tuổi bệnh nhân, nghĩa là tuổi bệnh nhân càng cao thì số lượng TBG trung mô trong DTX có xu hướng càng giảm, tuy nhiên mối tương quan này rất yếu với $r=-0,06$

\section{BÀN LUÂ̂N}

- Đắc điểm số lượng TB của tủy xương. Bằng phương pháp tế bào học kinh điển kết hợp với phân tích tế bào bằng hệ thống phân tích huyết học tự động, số lượng, thành phần và tỷ lệ các tế bào của tủy xương được xác định. Bảng 1 cho thây giá trị trung bình cưa các chỉ số tế bào của tủy xương đều nằm trong giới hạn bình thường của người Viêt Nam trưởng thành. Khi so sánh kết quả nghiển cứu của chúng tôi với nghiên cứu của Nguyễn Mạnh Khánh, Nguyễn Thanh Bình và cộng sự [8], [9] thấy rằng, tỷ lệ và số lượng TBG tạo máu (tế bào $\operatorname{CD} 34(+)$ ) trong tủy xương của chúng tôi có sự chênh lệch so với các tác giả (Bảng 5), điều này có thể được giải thích do sự khác nhau về một số đặc điểm đối tượng nghiên cứu như tuổi, mặt bệnh, cõ mẫu...

Nghiên cứu của Đỗ Trung Phấn trên 79 người Việt Nam trưởng thành cho thấy số lượng tế bào CD34(+) trung bình trong tủy xương là $1,22 \pm$ $0,79 \mathrm{G} / \mathrm{L}$. Tuy nhiên, phương pháp xác định tế bào $\mathrm{CD} 34(+)$ của nghiên cứu này khác với chúng tôi: sử dụng kỹ thuật huỳnh quang trực tiếp, 
đếm trên kính hiển vi huỳnh quang. Mặt khác, tỷ lệ và số lượng các tế bào tủy xương còn phụ

Bảng 5. So sánh kêt quả nghiên cứu của chúng tôi với một số tác giả khác về số lượng, tý lệ tế bào CD34(+) của tủy xương

\begin{tabular}{|c|c|c|c|c|} 
& Đơn vị & $\begin{array}{c}\text { Nguyền Mạnh Khánh } \\
(\mathbf{n = 6 5})\end{array}$ & $\begin{array}{c}\text { Nguyền Thanh Bình } \\
(\mathbf{n = 1 1 2})\end{array}$ & $\begin{array}{c}\text { Chúng } \\
\text { tôi }(\mathbf{n = 4 6 )})\end{array}$ \\
\hline Tế bào & $\mathrm{G} / \mathrm{L}$ & $0,4 \pm 0,2$ & $0,42 \pm 0,31$ & $0,56 \pm 0,93$ \\
\cline { 2 - 5 } $\mathrm{CD34}(+)$ & $\%$ & $0,6 \pm 0,2$ & $0,66 \pm 0,27$ & $0,71 \pm 0,78$ \\
\hline
\end{tabular}

Nghiên cứu của Major cho thấy, trong mỗi 1 $\mathrm{ml}$ dịch tuỷ xương lấy từ xương chậu của người khoẻ mạnh, có $92 \pm 65$ triệu tế bào có nhân, trong 23.000 tế bào có nhân thì có 1 tế bào gốc tạo sụn. Kết quả nghiên cứu của chúng tôi cho thấy, số lượng tế bào có nhân tuỷ xương trung bình là 69,03G/L (tương đương 69,03 triệu tế bào có nhân trong $1 \mathrm{ml}$ ) (Bảng 1 ), trong đó, thành phần tế bào $\operatorname{CD} 34(+)$ chiếm $0,71 \%$. Theo Biểu đồ 1 , số lượng tế bào CD34(+) tương quan tỷ lệ thuận với số lượng tế bào có nhân ( $r=$ $0,72, P<0,05)$. Theo Đố Trung Phấn, số lượng tế bào có nhân tuỷ xương của người Việt Nam trưởng thành trung bình $57,4 \pm 15,5 \mathrm{G} / \mathrm{L}$ [10]. Kết quả nghiên cứu của chúng tôi phù hợp với nghiên cứu của Major, Đỗ Trung Phấn và một số tác giả khác.

Để tìm hiểu số lượng tế bào tuỷ xương có bị ảnh hưởng bởi một số yếu tố tuổi tác, chúng tôi chia ra hai nhóm tuổi " $>55^{\prime \prime}$ và " $\leq 55^{\prime \prime}$ thấy rằng, tỷ lệ tế bào $C D 34(+)$, số lượng tế bào có nhân ở nhóm " > 55 tuổi " thấp hơn so với nhóm " $\leq 55$ tuổi " (Bảng 2), tuy nhiên sự khác biệt này không có ý nghĩa thống kê với $p>0,05$. Nhưng khi chia độ tuổi thành hai nhóm trên và dưới 50 tuổi thấy có mối tương quan tỷ lệ nghịch giữa tuổi và số lượng tế bào có nhân tủy xương $(p<0,05)$, nghĩa là tuổi càng cao thì số lượng tế bào có nhân càng giảm. Kết quả này phù hợp với nghiên cứu của Nguyễn Mạnh Khánh, Nguyễn Thanh Bình [8] [9].

Bảng 6. So sánh kêt quả nghiên cứu của chúng tôi với một số nhóm tác giả khác về thành phần tế bào có nhân, đơn nhân và tiểu câuu trong khôi TBGTX

\begin{tabular}{|c|c|c|c|c|}
\hline $\begin{array}{c}\text { Thành phần tế } \\
\text { bào }\end{array}$ & Đơn vị & $\begin{array}{c}\text { Nguyền Manh } \\
\text { Khánh (n=65) }\end{array}$ & $\begin{array}{c}\text { Nguyê̂n Thanh } \\
\text { Bình }(\mathbf{n = 1 1 2})\end{array}$ & Chúng tôi $(\mathbf{n = 4 6 )})$ \\
\hline TB có nhân & $\mathrm{G} / \mathrm{L}$ & $44,5 \pm 26,0$ & $47,36 \pm 30,12$ & $66,33 \pm 46,12)$ \\
\hline TB đớn nhân & $\%$ & $59,0 \pm 13,8 \%$ & $58,31 \pm 14,18$ & $60,05 \pm 14,98$ \\
\hline Tiếu câuu & $\mathrm{G} / \mathrm{L}$ & & $337,17 \pm 217,73$ & $468,26 \pm 306,24$ \\
\hline
\end{tabular}

TBG tạo máu (HSC) là loại TBG của tủy xương được nghiên cứu ứng dụng từ khá lâu trong điều trị các bệnh lý của cơ quan tạo máu và hố trợ điều trị một số bệnh ung thư của tổ chức rắn. Gần đây, người ta đã phát hiện ra khả năng biệt hóa "mềm dẻo" của TBG tạo máu, đó là khả năng chuyển biệt hóa (transdifferentiation), nhờ
- Đặc điểm thành phân tế bào và chất lượng khối TBG tách từ DTX. Sau quy trình chiết tách cô đặc, khối tế bào đơn nhân giàu TBG (được gọi là khối TBG) của tủy xương được huyền dịch trong $10 \mathrm{ml}$ huyết thanh mặn đẳng trương và được bơm vào khớp gối trong vòng 12 giờ. Trước khi ghép cho bệnh nhân, khối TBG được lấy mẫu để tiến hành các xét nghiệm kiểm tra vi khuẩn học. Kết quả $100 \%$ các mẫu khối TBG được cấy khuẩn cấy nấm đều âm tính, chứng tỏ các qui trình thu gom DTX, qui trình xử lý chiết tách cô đặc khối TBG được đảm bảo vô khuẩn tuyệt đối, khối TBG được bơm vào khớp gối đảm bảo an toàn về mặt vi khuẩn học. Việc đếm số lượng tế bào giúp mang lại những thông tin hữu ích về nồng độ tế bào trong một mililitre, tổng số lượng tế bào thu được của quá trình chọc hút thu gom dịch tủy xương cũng như của khối tế bào đớn nhân thu được sau khi xử lý cô đặc. Kết quả ở Bảng 3 cho thấy, trong khối TBG thu được có nồng độ tế bào có nhân trung bình là $66,33 \pm 46,12 \mathrm{G} / \mathrm{l}$, trong đó tế bào đơn nhân chiếm đa số $(60,05 \pm 14,98 \%)$; nồng độ tiểu cầu trung bình là 468,26 $\pm 306,24 \mathrm{G} / \mathrm{l}$. Khi đối chiếu với kết quả nghiên cứu của Nguyễn Thanh Bình, Nguyễn Mạnh Khánh và cộng sự, chúng tôi thấy kết quả nghiên cứu của chúng tôi có sự tương đồng về số lượng tế bào có nhân, số lượng tiểu cầu và tỷ lệ thành phần tế bào đơn nhẩn trong khối tế bào gốc tủy xương sau tách (Bảng 6). đó các nghiên cứu ứng dụng TBG tạo máu trong điều trị tái tạo các cơ quan tổ chức rắn bắt đâu được tiến hành.

Để xác định số lượng các TBG tạo máu trong khối TBG chúng tôi sử dụng phương pháp đếm số lượng tế bào $\operatorname{CD} 34(+)$. Theo Bảng 1 , trong khối TBG thu được, tỷ lệ tế bào CD34(+) trung 
bình chiếm 1,44\% (tăng gấp đôi so với trước tách), số tế bào $\operatorname{CD} 34(+)$ trung bình bơm vào khớp gối là 8,55 ( $\pm 5,5)$ x $10^{6}$ tế bào. Số lượng tế bào $\mathrm{CD} 34(+)$ tương quan tỷ lệ thuận với số lượng tế bào có nhân với $r=0,72, p<0,05$ (Biểu đồ 1).

TBG trung mô (MSC) là những tế bào đệm của tủy xương, dưới các tác động kích thích của các yếu tố phát triển, TBG trung mô có thể biệt hóa thành các tế vào có nguồn gốc trung mố, trong đó có tế bào sụn khớp.Thành phần TBG trung mô được chúng tôi xác định bằng nuôi cây cụm, theo đó mỗi TBG trung mô sau nuôi cấy trong 2 tuần sẽ mọc một cụm CFU-F [7]. Dựa vào số cụm CFU-F để xác định được số TBG trung mô được bơm vào khớp gối (Bảng 4).

Đối chiếu kết quả nghiên cứu của chúng tôi với các tác giả Nguyễn Mạnh Khánh, Nguyễn Thái Bình và cộng sự thây rằng tỷ lệ tế bào CD34(+), số cụm CFU-F $/ 10^{6}$ tế bào của khối TBG là tương đương. Số cụm CFU-F/ml khối TBG của chúng tôi gần gấp 3 lần so với Nguyễn Thanh Bình và Nguyễn Mạnh Khánh, điều này được lý giải vì thể tích cô đặc khối TBG của chúng tôi là $10 \mathrm{ml}$, trong khi đó thể tích cô đặc khối TBG của Nguyễn Thanh Bình và Nguyễn Mạnh Khánh là $30 \mathrm{ml}$ (Bảng 7) [8], [9].

Bảng 7. So sánh kêt quả nghiên cứu của chúng tôi với một số nhóm tác giả khác về thành phần tê bào CD34(+), số cụm CFU-F trong khối TBGTX

\begin{tabular}{|c|c|c|c|}
\hline \multicolumn{1}{|c|}{ NB } & $\begin{array}{c}\text { Nguyến Thanh } \\
\text { Bình }\end{array}$ & Nguyễn Mạnh Khánh & Chúng tôi \\
\hline Tỷ lệ TB CD34(+) & $1,23 \pm 0,69 \%$ & $1,3 \pm 0,5 \%$ & $1,44 \pm 0,67 \%$. \\
\hline Cụm CFU-F/10 TB & $53,43(11-112)$ & $25(15-39)$ & $43,17(7-140)$ \\
\hline $\begin{array}{c}\text { Cụm CFU-F/ml khối } \\
\text { TBGTX }\end{array}$ & $\begin{array}{c}1746,99(96,8- \\
5946,6)\end{array}$ & $1026(364-1996)$ & $\begin{array}{c}3336,8(283,9- \\
22698)\end{array}$ \\
\hline
\end{tabular}

Liên quan giữa số lượng tế bào tạo cụm CFU-F và tuổi, Biểu đồ 2 cho thấy, số cụm CFU-F có xu hướng tương quan tỷ lệ nghịch với tuổi bệnh nhân, tuy nhiên mối tương quan này không chặt chẽ ( $r$ $=-0,06, p>0,05)$. Đồng thời qua Biểu đồ 3.8 cho thấy số cụm CFU-F có xu hướng tương quan tỷ lệ thuận với số lượng tế bào đơn nhân $(r=0,27)$. Kết quả này phù hợp với các nghiên cứu khác.

\section{KẾT LUẬN}

Số lượng tế bào có nhân tủy xương trung bình là $69,03 \pm 49,86 \mathrm{G} / \mathrm{L}$. Tỷ lệ tế bào gốc CD34(+) tủy xương trung bình chiếm 0,71 \pm $0,78 \%$. Số lượng tế bào đơn nhân tương quan tỷ lệ nghịch với tuổi bệnh nhân. Số lượng và tỷ lệ tế bào CD34(+) không có sự khác biệt giữa hai nhóm trên và dưới 55 tuổi, ở hai nhóm tuổi trên và dưới 50 tuổi, có sự tướng quan tỷ lệ nghịch giữa tuổi và số lượng, tỷ lệ tế bào CD34(+), nghĩa là tuổi càng cao, tỷ lệ và số lượng tế bào gốc CD34(+) càng thấp.

Trong khối tế bào gốc tủy xương tự thân sau khi tách và cô đặc từ $120 \mathrm{ml}$ dịch tủy xương, tỷ lệ tế bào gốc $C D 34(+)$ chiếm 1,44 $\pm 0,67 \%$. Tổng số lượng tế bào gốc CD34(+) được tiêm vào khớp gối bệnh nhân trung bình là $8,15 \pm 5,5 x$ $10^{6}$ tế bào. Có mối tương quan tỷ lệ thuận giữa số lượng tế bào $\mathrm{CD} 34(+)$ và số lượng tế bào có nhân $(r=0,72, p<0,05)$.

Số lượng cụm CFU-F thu được khi nuôi cấy từ $1 \times 10^{6}$ tế bào trong khối tế bào gốc tủy xương trung bình là $43,17 \pm 25,23$ cụm, số lượng tế bào tạo cụm CFU-F được tiêm vào khớp gối trung bình là 33343,88 (2838-226980) cụm. Có mối tương quan tỷ lệ thuận giữa số lượng tế bào tạo cụm CFU-F với số lượng tế bào đơn nhân trong khối tế bào gốc tủy xương $(r=0,27)$, và tỷ lệ nghịch giữa số lượng tế bào tạo cụm CFU-F với tuổi bệnh nhân $(r=-0,06)$.

\section{TÀI LIÊU THAM KHẢO}

1. Trần Ngọc Ân (1995). Hư khớp và hư cột sông, bênh thấp khớp.

2. Christopher $J$ (2011). The Use of Mesenchymal Stem Cells in Orthopedics: Review of the Literature, Current Research, and Regulatory Landscape. Journal of American Physicians and Surgeons, 16.

3. Wakitani $S$ và Goto $T$ (2008). Mesenchymal cell-based repair of large, full-thickness defects of articular cartilage. J Bone Joint Surg Am, 76, 579-92.

4. Centeno CJ và Okabe T S.J.R. (2011). Safety and complications reporting update on the reimplantation of culture-expanded mesenchymal stem cells using autologous platelet lysate technique. Curr Stem Cell Res Ther.

5. Altman $R$ (1986). ACR Clinical Classification Criteria for Osteoarthritis of the knee. Arthritis Rheum, 29.

6. Kellgren J.H và Lawrence J.S (2957). Radiologic assessment of osteoarthritis. Rheum Dis, 16, 494-501.

7. (2005), Culture of Human and Mouse Mesenchymal Cells. Methods in Molecular Biology, .

8. Nguyến Manh Khánh (2011), Nghiên cứu ứng dưng ghép tế bào gốc tuỳ xương tự thân điêu trị chậm liên xương, khớp giả thân xương chày, Học viện Quân Y. 